\title{
Urban Farming: Teknologi Vertikultur Limbah Plastik untuk Mewujudkan Sekolah Dasar Berbasis Green School
}

\author{
Aditya Dyah Utami*, Mukti Ahmad Nur Cahya, Olivia Elfatma, Koko Setiawan \\ Akademi Komunitas Perkebunan Yogyakarta STIPER Yogyakarta \\ *Correspoding Author: aditya.du@akpy-stiper.ac.id
}

\begin{abstract}
ABSTRAK
Sekolah-sekolah dasar di area perkotaan umumnya memiliki ruang terbuka hijau yang minim. Hal tersebut menyebabkan pihak sekolah kesulitan untuk menerapkan program green school di dalam lingkungannya, salah satunya di SD Islamiyah Warungboto Yogyakarta. Salah satu solusi yang dapat dilakukan oleh pihak sekolah adalah mengenalkan teknologi vertikultur pada peserta didik. Pengenalan teknologi vertikultur dilaksanakan melalui 3 tahap, yaitu tahap persiapan, tahap pelaksanaan, dan tahap akhir. Peserta didik diberikan penjelasan tentang vertikultur secara umum lalu dilanjutkan dengan pelatihan pembuatan desain vertikultur. Melalui kegiatan pengenalan teknologi vertikultur, peserta didik mendapatkan pengetahuan tentang manfaat vertikultur. Selain itu, peserta didik dapat mengimplementasikan teknologi vertikultur dalam mendukung program green school.
\end{abstract}

Kata kunci: bercocok tanam, botol plastik, peserta didik, rak plastik, sayuran

\section{ABSTRACT}

Elementary schools, in urban area, generally have few green open space. This condition is a problem for elementary schools to implement green school programs in their environment. One of them is $S D$ Islamiyah Warungboto Yogyakarta. The introduction of verticulture technology to students can be an alternative solution for schools. The introduction of verticulture technology is carried out through 3 steps, namely the preparation step, the implementation step, and the final step. Students are given an explanation of verticulture in general and then proceed with training in verticulture design. Through these activities, students learn about verticulture and its benefits. In addition, students can implement verticultural technology to support green school programs.

Keywords: farming; plastic bottles; plastic shelves; students; vetegables

\section{PENDAHULUAN}

Lahan pertanian di perkotaan yang semakin menurun mengakibatkan masyarakat kota Indonesia beralih pada sistem pertanian modern salah satunya urban farming. Urban farming merupakan pertanian dengan memanfaatkan lahan kosong di perkotaan baik untuk hortikultura atau peternakan (Sihgiyanti, 2016; Abu \& Soom, 2016; Abera et al, 2017). Urban farming saat ini telah diadopsi tidak hanya lingkup rumah tangga tetapi instansiinstansi pemerintah juga menerapkan kegiatan tersebut salah satunya sekolah dasar.

Penerapan urban farming di lingkungan sekolah dasar umumnya bertujuan untuk meningkatkan ruang terbuka hijau dan memberikan pengenalan kepada peserta didik mengenai bercocok tanam. Urban farming yang saat ini banyak diaplikasikan di sekolah dasar yaitu teknologi vertikultur. Vertikultur adalah penanaman tanaman secara bertingkat (Surtinah \& Nurwati, 2018; Yosandy et al, 2018). Vertikultur banyak diaplikasikan di sekolah dasar karena keterbatasan lahan terbuka hijau yang dapat digunakan untuk bercocok tanam. Penanaman menggunakan teknologi vertikultur dapat diaplikasikan pada tanaman hias, hortikultur maupun buah-buahan (Sitawati et al, 2016; Sitawati, 2018). Aplikasi dan pengembangan vertikultur di sekolah dasar juga sebagai salah satu bentuk partisipasi terhadap pemerintah dalam menggalakkan program sekolah berbasis green school dan pengelolaan 
sampah dengan sistem reuse, reduce, recycle (3R). Program pengelolaan sampah sistem 3R dapat dilakukan dengan memanfaatkan barangbarang bekas sebagai vertikultur seperti botol plastik dan rak plastik bekas (Gaidajis et al, 2010; Karya et al, 2015). Hal ini bertujuan untuk mengurangi pencemaran sampah plastik di lingkungan. Pemanfaatan sampah plastik juga pernah dilakukan dalam kegiatan pengabdian kepada masyarakat oleh Merawati \& Nafi'ah (2018) di daerah Singojayan, Wirobrajan, Yogyakarta. Sampah plastik tersebut dimanfaatkan sebagai media tanaman obat keluarga (toga).

Oleh karena itu, teknologi vertikultur sangat tepat diaplikasikan dan dikembangkan pada lingkup sekolah dasar khususnya SD Islamiyah Warungboto. SD Islamiyah Warungboto merupakan sekolah dasar yang lokasinya dekat dengan pusat kota Yogyakarta dan merencanakan program sekolah berbasis green school. Namun, SD Islamiyah Warungboto memiliki ruang terbuka hijau yang relatif sempit sehingga perlu dilakukan transfer teknologi vertikultur sebagai solusi untuk mengatasi masalah tersebut. Berdasarkan uraian tersebut maka dilaksanakan kegiatan pengabdian kepada masyarakat di SD Islamiyah yang bertujuan memberikan pengetahuan dan mengimplementasikan vertikultur sehingga pelaksanaan program green school tercapai.

\section{METODE}

Kegiatan pengabdian kepada masyarakat dilaksanakan di SD Islamiyah Warungboto yang beralamat Jalan Prof. Dr. Soepomo, SH No 75b Umbulharjo Yogyakarta. Jumlah peserta didik di SD Islamiyah Warungboto dari kelas 1 sampai 6 SD yaitu 40 peserta. Kegiatan ini diikuti oleh seluruh peserta didik SD Islamiyah Warungboto. Pelaksana program ini dilakukan oleh dosen AKPY STIPER dengan diikuti 40 peserta didik SD Islamiyah. Metode yang digunakan dalam kegiatan ini adalah sosialisasi, demonstrasi dan implementasi. Terdapat tiga tahapan dalam kegiatan ini, yaitu tahap persiapan, tahap pelaksanaan dan tahap akhir.

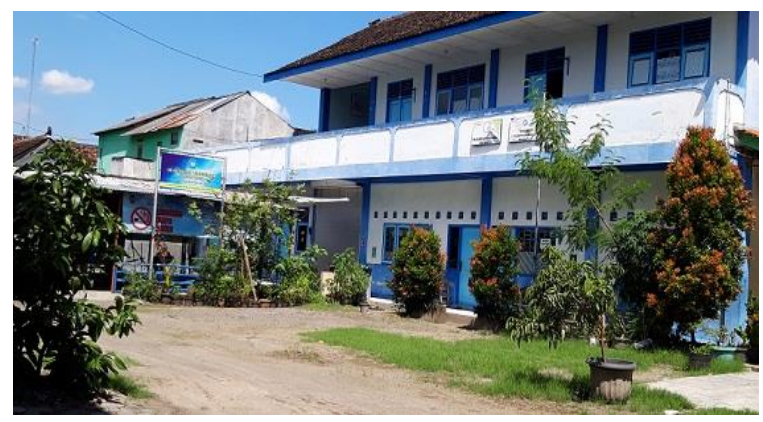

Gambar 1. SD Islamiyah Warungboto

Tahap persiapan bertujuan untuk mengetahui peran dan manfaat dari kegiatan yang akan dilaksanakan. Tahapan ini meliputi survei tempat pelaksanaan kegiatan, observasi dan wawancara dengan pihak sekolah, pengumpulan data siswa dan kegiatan. Kegiatan selanjutnya yaitu pelaksanaan program. Pelaksanaan program dilakukan dengan penyampaian materi oleh dosen AKPY STIPER mengenai vertikultur. Penyampaian materi ini meliputi pengertian vertikultur, manfaat vertikultur dan contoh implementasi vertikultur yang saat ini telah banyak dikembangkan oleh masyarakat. Kegiatan selanjutnya yaitu demonstrasi pembuatan desain vertikultur dari barang-barang bekas berupa botol dan rak plastik serta penanaman benih sayuran. Pembuatan desain dan penanaman benih sayuran ini dilaksanakan oleh peserta didik SD Islamiyah Warungboto didampingi oleh dosen AKPY STIPER dan guru wali kelas. Tahapan terakhir yang dilaksanakan adalah pengamatan sebelum dan setelah kegiatan, monitoring dan evaluasi. Monitoring dan evaluasi dilakukan dengan melakukan diskusi dengan pihak sekolah dan peserta didik yang mengikuti kegiatan. Setelah kegiatan berlangsung dilakukan diskusi dengan peserta didik. Setelah 7 dan 14 hari pelaksanaan dilakukan monitoring dengan meninjau ke sekolah.

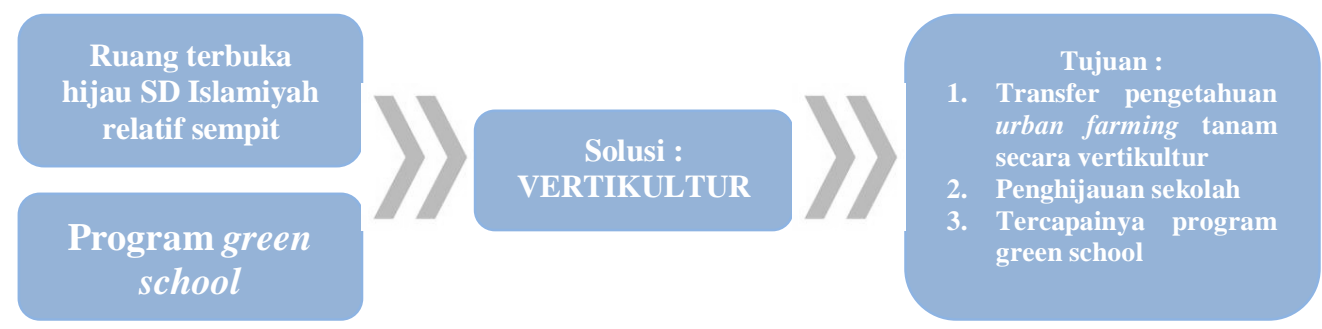

Gambar 2. Alur kegiatan yang dilakukan 


\section{HASIL DAN PEMBAHASAN}

SD Islamiyah Warungboto terletak di dekat pusat kota Yogyakarta dengan jumlah peserta didik sebanyak 40 siswa. Terdapat peserta didik dengan kebutuhan khusus sebanyak 15 siswa. Sebaran peserta didik SD Islamiyah sebagai berikut:

Tabel 1. Jumlah peserta didik SD Islamiyah yang mengikuti kegiatan

\begin{tabular}{cc}
\hline Kelas & $\begin{array}{c}\text { Jumlah Siswa } \\
\text { Tahun Ajaran 2019/2020 }\end{array}$ \\
\hline 1 & 11 \\
2 & 2 \\
3 & 3 \\
4 & 3 \\
5 & 10 \\
6 & 11 \\
\hline Jumlah & 40 \\
\hline
\end{tabular}

Sumber: Data primer diolah (2020)

Ruang terbuka hijau di SD Islamiyah Warungboto relatif sempit (Gambar 1). Tanaman yang ditanam pada area tersebut hanya beberapa macam seperti tanaman hias, buah, sayuran (daun bawang, seledri) serta rempahrempah. Oleh karena itu, perlu dilakukan edukasi tentang bercocok tanam untuk meningkatkan pengetahuan peserta didik. Harapannya dapat mendukung pengembangan sekolah berbasis green school.

Pelaksanaan kegiatan pengabdian kepada masyarakat ini yaitu persiapan alat dan bahan, persiapan tata letak vertikultur, penyampaian materi dan demonstrasi desain vertikultur kepada siswa SD Islamiyah Warungboto.

\section{Persiapan alat dan bahan}

Alat dan bahan yang digunakan antara lain botol plastik, rak plastik, sekop, ember, media tanam (tanah, pupuk kandang), benih sayuran (kangkung, bayam, cabai, tomat) (Gambar 3). Botol plastik bekas air mineral dipotong menjadi dua bagian. Kemudian bagian bawah botol dibersihkan dan dilubangi. Rak plastik bekas juga dibersihkan dan dilubangi. Pemanfaatan limbah plastik ini bertujuan untuk mengurangi jumlah limbah yang umumnya sulit terurai sehingga mencemari lingkungan (Sofiana, 2010; Grigore, 2017; Diwanti, 2018). Pencemaran akibat limbah plastik di lingkungan antara lain tersumbatnya saluran irigasi, pendangkalan sungai/waduk, mengganggu ekosistem perairan serta dapat menurunkan kesuburan tanah (Alighiri, 2019)

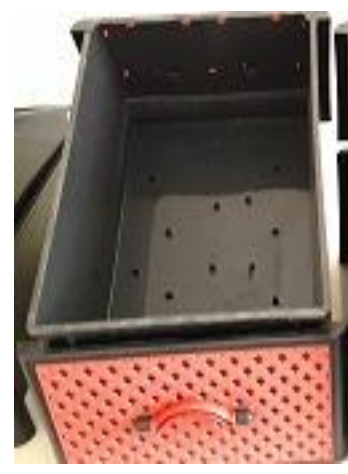

(a)

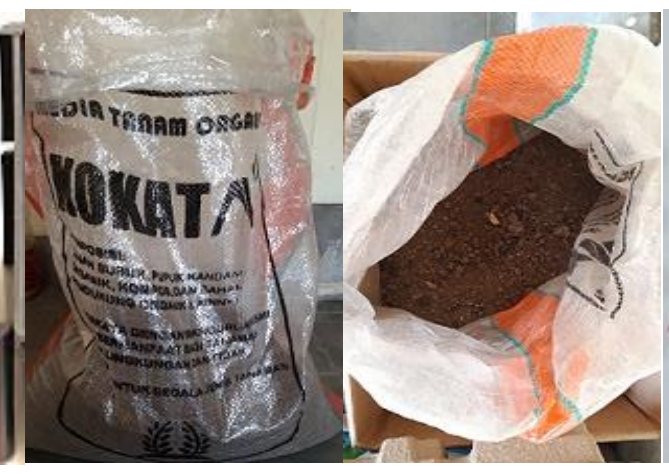

(b)

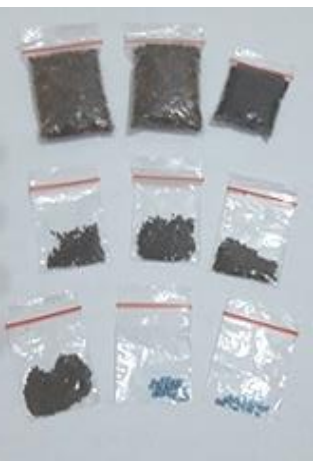

(c)

Gambar 3. Alat dan bahan pembuatan vertikultur (a) rak plastik (b) media tanam (c) benih

\section{Persiapan tata letak vertikultur}

Persiapan tata letak ini dilakukan bersama dengan pihak sekolah untuk mengetahui ruang terbuka yang dapat dijadikan vertikultur. Berdasarkan pengamatan yang dilakukan oleh dosen AKPY STIPER dan pihak sekolah, area yang dapat digunakan adalah di depan ruang kelas, parkir sepeda motor guru dan didepan mushola. Ketiga area ini dipilih berdasarkan beberapa pertimbangan antara lain tidak mengganggu aktivitas siswa dalam belajar mengajar, cukup terkena cahaya matahari serta dekat dengan kran air. Cahaya matahari dan air merupakan faktor penting bagi pertumbuhan tanaman. Tanaman memerlukan kedua sumberdaya tersebut untuk fisiologisnya sehingga mampu tumbuh dan berproduksi dengan baik (Pan \& Guo, 2016).

\section{Penyampaian materi dan demonstrasi desain vertikultur}


Penyampaian materi meliputi pengertian, macam dan manfaat vertikultur. Selain itu juga disosialisasikan mengenai manfaat lingkungan hijau dalam mendukung kegiatan belajar mengajar di sekolah (Gambar 4). Kegiatan selanjutnya adalah demonstrasi desain vertikultur menggunakan alat dan bahan yang telah dipersiapkan. Metode pengajaran demonstrasi kepada peserta didik ini diharapkan dapat membuat materi yang disampaikan lebih mudah dipahami. Karena metode tersebut diperagakan bagaimana cara membuat vertikultur dengan baik sehingga mudah ditiru oleh peserta didik (Widyanto \& Rabiman, 2016; Sucipto, 2017). Desain vertikultur menggunakan botol plastik dilakukan dengan menyusun secara

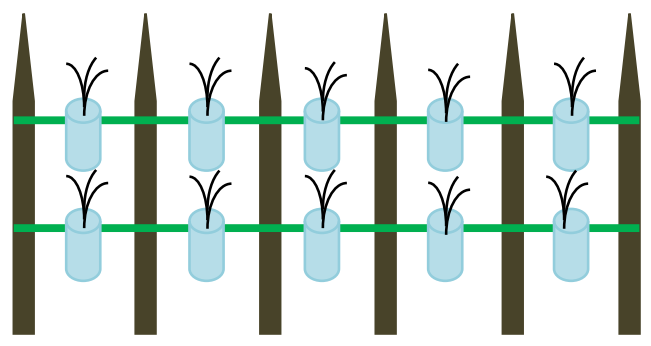

(a) vertikal pada pagar kayu di halaman (Gambar 5a). Vertikultur dengan rak plastik akan disusun bertumpuk secara vertikal (Gambar 5b).

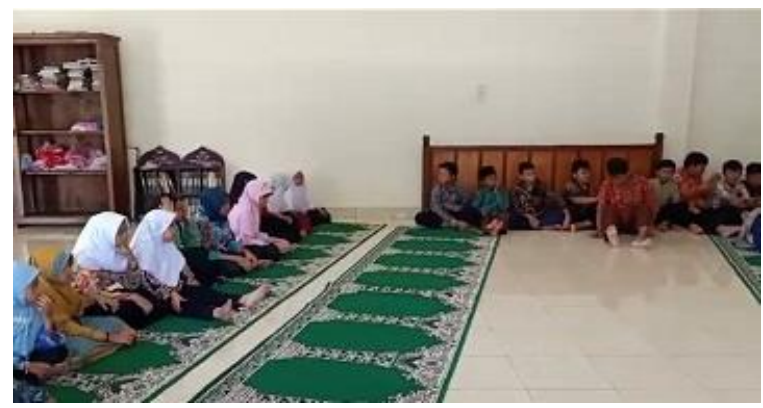

Gambar 4. Penyampaian materi vertikultur

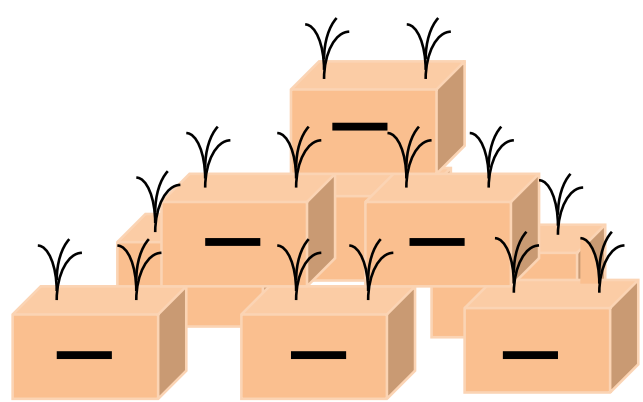

(b)

Gambar 5. Ilustrasi model vertikultur (a) botol plastik (b) rak plastik

\section{Pembuatan vertikultur}

Pelaksanaan pembuatan vertikultur oleh peserta didik SD Islamiyah dilakukan secara berkelompok. Pembagian kelompok disesuaikan dengan jumlah siswa yang ada di sekolah yaitu 10 kelompok. Masing-masing kelompok terdiri dari 4-5 siswa secara acak dari kelas 1 hingga 6 SD. Kemudian dibagikan alat dan bahan sebanyak 2 botol plastik, benih sayuran (kangkung dan bayam), media tanam kepada setiap kelompok. Vertikultur yang menggunakan rak plastik pembuatannya berbeda dengan botol plastik. Pembuatan vertikultur dengan rak plastik, peserta didik dibagi menjadi 6 kelompok besar secara acak dari kelas 1 hingga 6 SD. Kemudian setiap kelompok diberikan 1 rak plastik, benih sayuran (bayam, kangkung, cabai, tomat) dan media tanam kepada setiap kelompok.

Pelaksanaan kerja yang dilakukan dalam pembuatan vertikultur adalah menyiapkan media tanam yang terdiri dari tanah dan pupuk kandang dimasukkan ke dalam botol maupun rak plastik. Media tanam dimasukkan 1/3 dari volume botol maupun rak plastik. Setelah media tanam telah siap, dilakukan penyiraman pada media tanam dan diberi lubang tanam. Selanjutnya melakukan penanaman benih sayuran yang telah disiapkan. Aplikasi media tanam berupa pupuk kandang bertujuan untuk membantu ketersediaan hara bagi tanaman. Dawid (2018) menyatakan bahwa pemberian pupuk kandang sebagai pupuk organik juga meningkatkan kesuburan tanah.

Botol maupun rak plastik yang telah ditanami kemudian diberi label meliputi nama sayuran, nama anggota kelompok dan tanggal penanaman. Selanjutnya, meletakkan vertikultur tersebut pada 3 area yaitu depan ruang kelas, area parkir motor dan depan mushola. Setelah pelaksanaan selesai, peserta didik dihimbau untuk memelihara benih yang telah ditanam dengan cara melakukan penyiraman ketika kondisi tanah mulai kering. Peserta didik diberikan informasi perkiraan waktu panen. Selain itu, tim dosen juga meninjau vertikultur setelah hari ke-7 dan ke-14 penanaman (Gambar $6)$.

\section{Monitoring dan Evaluasi}

Monitoring dilakukan untuk memantau pelaksanaan pemeliharaan vertikultur yang dilakukan oleh peserta didik. Tujuannya supaya mengetahui keberlanjutan dan kemajuan kegiatan serta permasalahan yang muncul 
selama pelaksanaan berlangsung. Evaluasi dilakukan harapannya permasalahan yang muncul dapat diberikan solusi sehingga dapat menjadi bahan pertimbangan pelaksanaan kegiatan pengabdian selanjutnya. Monitoring dilakukan dengan meninjau langsung ke SD Islamiyah Warungboto untuk melihat keberhasilan kegiatan vertikultur. Evaluasi dilakukan dengan diskusi dengan pihak sekolah dan peserta didik. Monitoring dan evaluasi dilaksanakan pertama kalinya pada hari ke-7 setelah kegiatan.
Hasil monitoring dan evaluasi menunjukkan bahwa kegiatan tersebut memberikan informasi dan pengetahuan tambahan tentang vertikultur. Kendala yang dihadapi saat pelaksanaan kegiatan adalah ketersediaan alat/bahan yang terbatas sehingga tidak seluruh peserta didik terfasilitasi untuk melakukan praktek. Namun, kegiatan ini juga memberikan manfaat bagi peserta didik. Peserta didik lebih antusias untuk melakukan kegiatan bercocok tanam secara sederhana. Selain itu, peserta didik menjadi paham dengan jenis tanaman terutama sayuran dan hias.

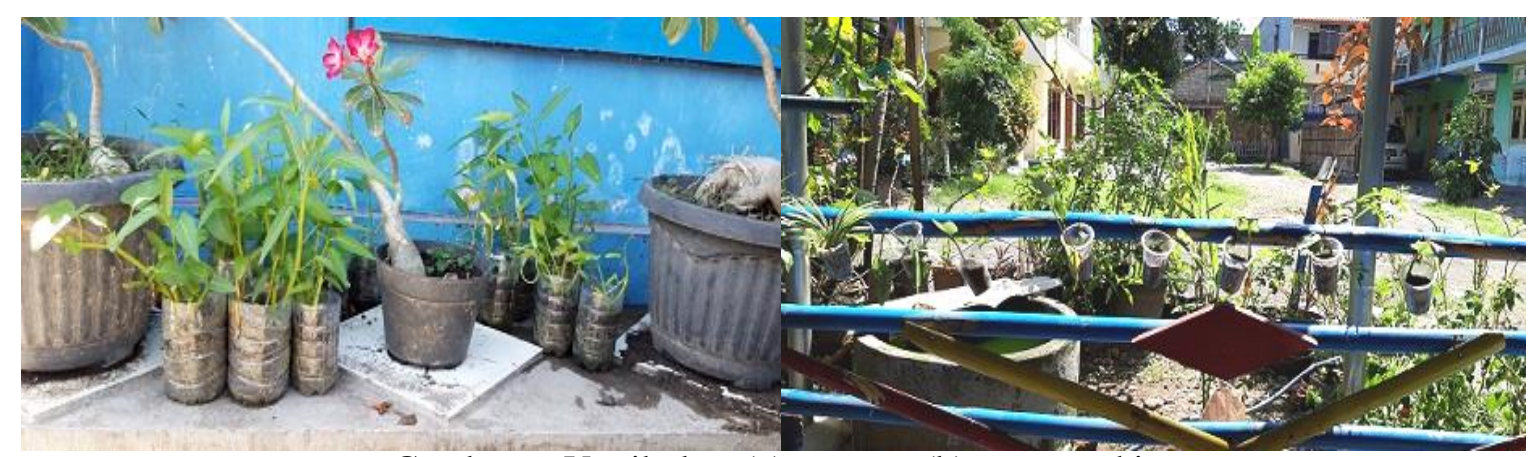

Gambar 6. Vertikultur (a) sayuran (b) tanaman hias

Tanaman yang ditanam sebagian tumbuh dengan baik sehingga meningkatkan hijauan di halaman sekolah. Oleh karena itu, kegiatan ini dapat membantu SD Islamiyah Warungboto dalam upaya mewujudkan sekolah berbasis green school. Namun, terdapat kendala yang muncul yaitu sebagian sayuran yang ditanam tidak tumbuh dengan optimal. Solusi yang dapat dilakukan yaitu dengan menyulam benih. Selain itu, dalam kegiatan monitoring dan evaluasi disampaikan cara melakukan pemelihaaran tanaman yang ditanam.

\section{KESIMPULAN}

Rangkaian pelaksanaan kegiatan tersebut di SD Islamiyah Warungboto disimpulkan bahwa peserta didik mendapatkan informasi dan pengetahuan tentang bercocok tanam secara vertikultur. Tumbuhnya benih yang ditanam menambah hijau halaman sekolah. Hal tersebut mendukung sekolah dalam mewujudkan green school. Selain itu, pemanfaatan barang bekas juga dapat mengenalkan sistem reuse, reduce, recycle (3R) kepada peserta didik. Harapannya, kegiatan ini masih terus berlanjut dengan melakukan pendampingan oleh dosen AKPY STIPER kepada peserta didik sampai panen. Selain itu, juga kerjasama secara keberlanjutan
AKPY dan SD Islamiyah Warungboto untuk melakukan transfer teknologi lain dalam upaya mendukung pelaksanaan program sekolah berbasis green school melalui urban farming.

\section{UCAPAN TERIMA KASIH}

Terima kasih kepada LPPM AKPY STIPER yang telah memberikan dana hibah pengabdian kepada masyarakat tahun 2019/2020.

\section{DAFTAR PUSTAKA}

Abera, A., Tadesse, G., Belayneh M., 2017. Practices, roles and challenges of urban agriculture in south western part of Ethiopia: the case of bedelle tow. International Journal of Scientific and Research Publications 7 (5): 609-610.

Abu, G.A., Soom, A., 2016. Analysis of factors affecting food security in rural and urban farming households of benue state, Nigeria. International Journal of Food and Agricultural Economics 4(1): 55-68.

Alighiri, D., Yasin, M.N., Rohmawat,i B., Drastisianti, A., 2019. Processing of recycled waste PET (polyethylene terephthalate) plastics bottle into for the 
lightweight and reinforcement bricks. Journal of Physics: Conference Series 18.

Dawid, J., 2018. Organic fertilizers requirement of coffe (Cffea Arabica L) Review. International Journal of Research Studies in Agricultural Sciences 4 (7): 11-18.

Diwanti, D.P., 2018. Pemanfaatan pertanian rumah tangga (pekarangan rumah) dengan teknik budidaya tanaman sayuran secara vertikultur. Jurnal Pengabdian Masyarakat 1 (3): 101-107.

Gaidajis, H., Angelakoglou, K., Aktsoglou, D., 2010. E-waste: environmental problems and current management. Journal of Engineering Science and Technology Review 3 (1): 193-199.

Grigore, M.E., (2017). Methods of recycling, properties and applications of recycled thermoplastic polymers. Recycling 1-11.

Karya, B., Hawalid, H., Hawayant,i E., 2015. Pengaruh jenis rakit limbah botol plastik dan jenis pupuk organic padat terhadap pertumbuhan dan produksi tanaman sawi (Brassica oleracea L. Var. alboglabra Bailey) di lahan rawa lebak yang tergenang. Klorofil 10 (2) : 106-110.

Merawati, F., Nafi'ah, B., 2018. Pemanfaatan sampah plastik untuk pemberdayaan tanaman toga dalam program penghijauan lingkungan Singojayan. Jurnal Pemberdayaan: Publikasi Hasil Pengabdian kepada Masyarakat 2 (3): 441-448.

Pan, J., Guo, B., 2016. Effevts of light intensity on the growth, photosynthetic characteristic, and flavonoid content of Epimedium pseudowushanense B.L.Guo. Molecules 1-12.
Sihgiyanti, V.J., 2016. Evaluasi implementasi program urban farming oleh dinas pertanian Kota Surabaya. Kebijakan dan Manajemen Publik 4 (2): 264-272.

Sitawati., Suryanto, A., Nurlaelih, E.E., 2016. Optimization of plant growth and yield through innovation of the verticultural materials and media. Research Journal of Life Science 3 (1): 55-64.

Sitawati., 2018. Growth response of Lactuca sativa to plant number per pocket and irrigation interval in planting bag wall. Bioscience Research 15 (3): 2679-2685.

Sofiana, Y,. 2010. Pemanfaatan limbah plastik sebagai alternative pelapis (upholstery) pada produk interior. Inasea 11 (2): 96102.

Sucipto., 2017. Peningkatan pemahaman cara berwudhu melalui penerapan metode demonstrasi dan simulasi di sekolah dasar. Brilliant: Jurnal Riset dan Konseptual 2 (1): 25-31.

Surtinah., Nurwati, N., 2018. Optimalisasi pekarangan sempit dengan tanaman sayuran pada kelompok ibu rumah tangga. Jurnal Pengabdian dan Pemberdayaan Masyarakat 2 (2): 193-199.

Widyanto, F., Rabiman., 2016. Penerapan metode demonstrasi untuk meningkatkan keaktifan dan hasil belajar mata pelajaran sistem kelistrikan. Jurnal Taman Vokasi 4 (2): 253-262.

Yosandy, D.S.O., Baskara, M., Herlina, N., 2018. Pengaruh media tanam pada sistem vertikultur terhadap pertumbuhan dan hasil tanaman. Jurnal Produksi Tanaman 6 (2): 210-216. 